\title{
THE SYSTEMS PSYCHODYNAMIC LEADERSHIP COACHING EXPERIENCES OF NURSING MANAGERS
}

\begin{abstract}
Authors:
Frans Cilliers $^{1}$

Landa Terblanche ${ }^{2}$

Affiliations:

${ }^{1}$ Department of Industrial and Organisational

Psychology, University of

South Africa, South Africa

${ }^{2}$ School of Nursing,

Trinity Western

University, Canada

\section{Correspondence to:}

Frans Cilliers

email:

cillifvn@unisa.ac.za

\section{Postal address:}

Department of Industrial and Organisational

Psychology, UNISA,

PO Box 392, Unisa 0003,

South Africa

\section{Keywords:}

coaching; task; role;

authorisation; boundaries; identity

Dates:

Received: 25 May 2009

Accepted: 25 Feb. 2010

Published: 15 July 2010

How to cite this article:

\section{ABSTRACT}

The mostly linear and mechanistic nature of the nursing manager role is rapidly becoming more dynamic and systemic. The change involves task and people management within a constantly changing organisational identity, taking up multiple leadership roles, having to authorise oneself and others in a complex matrix system, and managing conscious and unconscious psychological boundaries within and between conflicting systems. The aim of this study was to describe the systems psychodynamic learning experiences of nursing managers during leadership coaching. The coaching task was to provide learning opportunities to the individual leader, towards gaining insight into conscious and unconscious leadership dynamics in terms of anxiety, task, role, authorisation, boundaries and identity. A qualitative research design was used. Six nursing managers attended ten leadership coaching sessions over ten weeks. Field notes and reflective essays were analysed using systems psychodynamic discourse analysis. The findings indicated clarity and authorisation in the participants' primary task and normative roles; anxiety and de-authorisation in their experiential and phenomenal roles; anxiety in boundary management related to the misuse of power by others; and the continuous exploration of their leadership role identity towards achieving integration. Participants' learning experiences were evaluated in terms of criteria for organisational learning, after which a general hypothesis was formulated.

\section{OPSOMMING}

Die meestal liniêre en meganistiese aard van die verpleegbestuursrol is vinnig besig om na ' $n$ meer dinamiese en sistemiese rol te verander. Die verandering behels taak- en mensbestuur binne 'n steeds veranderende organisasie-identiteit, waar 'n verskeidenheid rolle opgeneem word, die self en ander in 'n komplekse matrikssisteem bemagtig word, en waartydens bewuste en onbewuste sielkundige grense in en tussen botsende sisteme bestuur word. Die doel van hierdie studie was om die sisteem-psigodinamiese leerervaringe van verpleegbestuurders tydens leierskapafrigting te beskryf. Die afrigtingstaak was om leergeleenthede aan die individuele leier beskikbaar te stel vir die ontwikkeling van insig in bewuste en onbewuste leierskapsdinamika in terme van angs, taak, rol, outoriteit, grense en identiteit. 'n Kwalitatiewe navorsingsontwerp is gebruik. Ses verpleegbestuurders het tien leierskapafrigtingsessies oor tien weke bygewoon. Veldnotas en besinnende opstelle is deur middel van sisteem-psigodinamiese gespreksanalise ontleed. Die bevindinge dui op duidelikheid oor en bemagtiging in hulle primêre taak en normatiewe rol; angs en ontmagtiging in hulle ervarings- en fenomenale rolle; angs in grenshandhawing wat verband hou met magsmisbruik deur andere; en die voortdurende ondersoek en integrasie van leierskapsrolidentiteit. Deelnemers se leerervarings is na aanleiding van kriteria vir organisasieleer geëvalueer, waarna die algemene hipotese geformuleer is.
\end{abstract}

Cilliers, F. \& Terblanche, L., 2010, 'The systems

psychodynamic leadership coaching experiences of nursing managers', Health SA Gesondheid 15(1),

Art \#457, 9 pages. DOI:

10.4102/hsag.v15i1.457

This article is available at:

http:/ / www.hsag.co.za

\section{(C) 2010. The Authors.}

Licensee: OpenJournals Publishing. This work is licensed under the Creative Commons Attribution License.

\section{INTRODUCTION}

The post-modern world of work demands that leadership be aware of and stay involved in increasingly competitive and complex technical and interpersonal organisational systems (Clutterbuck 2003; Willem 2003). These systems contain constant change, conflict, chaos, paradox and limited resources (Meyer \& Boninelli 2007; Will \& Codrington 2004). As a result, leaders experience high levels of survival and performance anxiety, they feel disorientated, lost, lonely, doubtful, not 'good-enough', vulnerable and under constant pressure to perform their task and manage their relationships effectively (Huffington et al. 2004; Kets de Vries 1991, 2001; Levinson 2006). In health care in South Africa, these demands manifest as the depletion of emotional resources, feelings of depersonalisation and a weak sense of coherence, as well as a lack of experienced organisational support (Van der Colff \& Rothmann 2009).

Worldwide, leadership or executive coaching is increasingly used to assist leaders to adapt to the demands mentioned above and their manifestations. Coaching is generally defined as a regular, shortterm and highly focused organisational learning opportunity (compared to therapy and traditional training), involving a helping relationship between a client who has managerial authority and responsibility in an organisation and a consultant who uses behavioural techniques and methods to help the client to improve personal insight towards effective leadership performance and, consequently, to improve the effectiveness of the client's organisation, all within the boundaries of a formally defined coaching agreement (Kets de Vries 2007; Kilburg \& Diedrich 2007; McKenna \& Davis 2009). The goal of coaching is to optimise leadership competence in the individual, and indirectly, in their teams and organisation (Lowman 2002; Sperry 2004). Most of the coaching studies mentioned in management and organisational psychology (Coutu \& Kaufman 2009; Goldsmith, Lyons \& Freas 2000; Harvard Business Essentials 2004; McGovern et al. 2001; Peterson 1996; Stern 2001), as well as in nursing (Orenstein 2007; Savage 2001), approach coaching from a mechanistic perspective and report results on cognitive learning about leadership. Coaching studies from a humanistic perspective (Stout Rostron 2009) make use of respect and empathy as constructs and report on the facilitation of self-awareness. Studies that approach coaching from a systemic and psychodynamic perspective, including experiential learning methods (Chapman \& Cilliers 2008; Cilliers 2005), reported comparatively deeper levels of 
self-awareness and insight in the role of leader and a compelling and dynamic connective quality in the human relationships in view of the organisation's vision, mission, culture and structure. These outcomes are linked to what Kets de Vries and Engellau (2007:32) refer to as creating the 'authentizotic organisation'.

\section{SYSTEMS PSYCHODYNAMIC LEADERSHIP COACHING}

The systems psychodynamic perspective was developed at the Tavistock Institute in London (Miller 1993) based on its annual international group relations training events over 60 years (Brunner, Nutkevitch \& Sher 2006; Fraher 2004). It consists of a depth psychology organisational theory (Armstrong 2005; Gould, Stapley \& Stein 2001) and an organisational development consultancy stance (Neumann, Keller \& Dawson-Shepherd 1997). The perspective is based on Freudian systemic psychoanalysis, group relations theory, object relations and open systems theory (Colman \& Bexton 1975; Colman \& Geller 1985; Cytrynbaum \& Noumair 2004) and is theoretically informed by five basic behavioural assumptions - namely, dependency, fight/flight, pairing (Bion 1961, 2003), me-ness (Turquet 1974) and one-ness / we-ness (Lawrence, Bain \& Gould 1996).

The primary task of the systems psychodynamic leadership coaching model is to provide developmentally and psychoeducationally focused reflection and learning opportunities to the individual leader, to study, become aware of and gain insight into how task and organisational performance are influenced by both conscious and unconscious behaviour (Brunning 2006; Huffington et al. 2004; Kets de Vries 2007; Newton, Long \& Sievers 2006). Consciousness refers to objectivity and rational behaviour, and unconsciousness to 'the organisation in the mind' which contains the system's unconscious defences and irrational behaviours (Armstrong 2005).

In service of the primary task, the systems psychodynamic leadership coaching model experientially investigates how the following behavioural constructs manifest in the leader's work life (Cilliers \& Koortzen 2005; Czander 1993; Gould et al. 2001; Klein 2005; Hirschhorn 1993):

- anxiety - defined as the fear of the future, acting as the driving force ('dynamo') of the relationship and relatedness between leadership and followership.

- task - the basic component of work, with the leader's adherence to the primary task indicating contained anxiety, and diversions into off-task and anti-task behaviour indicating confusion and free-floating anxiety.

- role - the boundary surrounding work and position, and between leader/follower/organisation, where leadership is defined as managing the boundaries between what is inside and what is outside the role, and where role dynamics differentiate between the normative, experiential and phenomenal.

- authority - the formal and official right to perform the task, bestowed from above (the organisation, manager, leader), the side (colleagues), below (subordinates) and within (selfauthorisation).

- boundaries - such as task, time, territory, which acts as the space around and between parts of the system, keeping it safe and contained.

- identity - the nature of the leader's role behaviour and the branding, climate and culture of the organisational system.

Operationally, the first leadership coaching session starts with role analysis, which provides the behavioural dynamics for the whole coaching procedure (Newton et al. 2006). The focus is not solely on the person (as in psychotherapy - McKenna \& Davis 2009) or on the organisation, but rather on the leader in role within the person-role-organisation interaction (Huffington et al. 2004). This means that the effect of the organisation on the role is also being studied. Leaders are asked to describe their normative (the objective job description/content, measured according to performance management), existential (how they believe they are performing) and phenomenal roles (how they believe they are performing as experienced by colleagues around them) (Brunning 2006; Obholzer \& Roberts 1994). The rationale is that the incongruence between the three role parts indicates role anxiety, which is worth studying for the purposes of insight and change (Newton et al. 2006). Each subsequent session starts with the open question, 'what is happening with you in your role as leader at the moment'. There are no specific aims for each session, in order to ensure the flow of the discourse in the hereand-now, which is different from using training methodologies (Kets de Vries 2007). The coach negotiates with the leader to make short notes during the session, which the leader also sometimes does.

The coach-leader relationship involves an intense discourse (Campbell \& Gronbaek 2006). The role of the coach is to take a reflective stance from a meta position, alert to the leader's behaviour, interpreting the manifestation of the basic assumptions and behavioural concepts referred to above without judgement, memory or desire (Campbell \& Huffington 2008). This is done by formulating working hypotheses, defined as an integrative statement of 'searching into' (Schafer 2003) the leader's experiences and by constantly re-visiting this content in the light of further and new manifesting evidence (Campbell 2007). Leaders are encouraged to be curious, to associate freely, to explore a variety of related feelings, patterns, defences and representations (including the transferences between coach and leader) and to move between different levels of abstraction in thought (Jaques 1990; Kegan 1994). Thus, such leaders can access their own unexplored conscious and unconscious role experiences, attitudes, beliefs, fantasies, wishes, conflicts, social defences, preferences, competition, rivalry, jealousy, envy, hostility, aggression as well as patterns of relationships and collaboration. They can investigate how parts of the self are split off and projected onto and into other parts of the organisational system (individuals, groups) who may have the valence for receiving and carrying the specific projections and who contain them on behalf of the system (projective identification). They can also consider what can be done to take back the projections and reclaim the lost parts of the self (Blackman 2004; Neumann et al. 1997; Shapiro \& Carr 1991; Stapley 1996, 2006).

\section{PROBLEM STATEMENT, RESEARCH QUESTION AND AIM OF THE RESEARCH}

The manifestation of the above organisational and behavioural demands in health care implies that the role of the nursing manager is also being transformed. The movement is from a traditional focus on the professional/technical, educational, administration and research fields, and the fairly mechanistic, linear and compartmentalised management of these, towards taking up a dynamic and systemic leadership role (Grossman \& Valiga 2009; Sullivan \& Decker 2009). Porter-O'Grady and Malloch (2007) refer to this movement as quantum leadership for health care innovation.

Operationally, thenew roleincludes task and people management within a constantly changing organisational identity, taking up multiple roles, having to authorise self and others in a complex matrix system and managing conscious and unconscious psychological boundaries within and between conflicting systems (Kets de Vries 2007). Because nursing managers are generally not educated, either formally or in-service, to understand and adapt to the these complex organisational and leadership demands, this study suggests bridging the gap by means of leadership coaching as an organisational development input. As a coaching model, a systems psychodynamic perspective is suggested here to address the implied behavioural depth and complexity (see Peltier 2001). 
The research question was formulated as follows: what are the manifesting systems psychodynamic learning experiences of nursing managers during leadership coaching that focus on the awareness of their dynamic role behaviour, their authorisation, boundary management and continuous identity formation? The aim was to describe the systems psychodynamic learning experiences of nursing managers during leadership coaching.

\section{RESEARCH METHOD AND DESIGN}

\section{Research approach}

The research design was qualitative and descriptive in nature (Breverton \& Milward 2004; Camic, Rhodes \& Yardley 2003). This implies that the researcher is interested in, and concerned about, socially relevant values and ethics, without being intimidated by power or status. The researcher asks the question 'what is actually happening', while exploring by means of continuous reflection and then describing the behaviour in the context of the theoretical framework - namely, systems psychodynamics. In this research study, a depth psychology perspective, which includes the manifestation of unconscious behaviour, was chosen in order to 'penetrate the illusion' (Higgs \& Smith 2003:67) that leadership is only about conscious behaviour. Thus the leadership reality, comprising conscious and unconscious behaviour, could be explained.

\section{Population and sampling}

The population consisted of nine senior nursing managers in a private hospital group working in different hospitals in Gauteng. They were informed about the researchers' leadership coaching project at a head office meeting. The project was framed as follows: it would be voluntary; the coaching would take place in their individual hospitals; since coaching is not a performance assessment intervention no coaching feedback would be given to their management; and there would be no cost involved for the individual manager or hospital. Head office agreed to pay the coach's travel expenses per coaching session to the different hospitals. Interested managers could phone the first author for an appointment for a chemistry meeting (a typical custom in coaching to allow both parties to ascertain whether they will be able to work with the other in a coaching relationship). All nine managers made appointments and during the meeting they were informed about the rationale, method and logistics of the leadership coaching programme. Six managers declared themselves willing for coaching while three withdrew from the procedure because of practical reasons and time constraints.

Thus, the voluntary and convenient sample (Henning, Van Rensburg \& Smit 2004) consisted of four White and two Black females, all responsible for a hospital unit with its nursing staff in a large hospital. This situation created a potential problem in terms of saturation, because up to this point the sample was a given in the sampling method. The researchers decided to accept the sample of six with the probability to enlarge the sample in case the material was not rich enough for interpretation.

\section{Procedure}

The sample of six nursing managers received 10 hours of individual leadership coaching, arranged as one-hour sessions over 10 weeks, held in the office of the participant. The aim of the sessions was to work on the primary task of systems psychodynamic leadership coaching, as described above. The first author conducted the sessions as described below. He is a psychologist (category industry) with a doctoral degree in Industrial and Organisational Psychology. His specific training of 12 years in systems psychodynamic coaching was congruent to the requirements described by Brunner et al. (2006) - namely, a solid theoretical systems psychodynamic knowledge, experience in systems psychodynamic consultancy and coaching through 'Tavistock' training by attending, being trained in and directing experiential group relations events, being coached and continuously being supervised whilst coaching clients.

\section{Data collection}

The data collection was carried out during and after the coaching sessions. During the sessions, the coach made field notes about the topics and themes which the leaders addressed and the manner in which they responded to the working hypotheses offered verbally by the coach. After the last session the participants were asked to write an essay of about five pages on their experiences of coaching with special reference to how they take up their normative, existential and phenomenal roles. These reflective essays were regarded as transcriptions representing the experience of each leader (Camic et al. 2003). Thus, the data consisted of the coach's field notes and the leaders' essays.

\section{Data analysis and interpretation}

System psychodynamic discourse analysis was used (Smit \& Cilliers 2006). This discourse is defined as the idea that concepts serve as the basis of thinking and are expressed by words, located in language (Campbell \& Huffington 2008). This speechact forms the central engagement point in the interaction. Thus, one may ascertain what discourses frame the language action, the way in which leaders make sense of their reality and how this discourse is produced and maintained in the social context (Terre Blanche et al. 2006; Van Manen 1990). The discourse markers related to the leaders' conceptions, values and beliefs about their experiences of the three different parts of their roles. In systems psychodynamic terms the unit of analysis is the individual leader and 'the organisation in her mind' (Armstrong 2005).

In interpreting the data, the researchers drew on their theoretical knowledge about the above-mentioned basic assumptions and relevant behavioural constructs which were being manifested, as well as on their subjective capacity to make sense of the dynamic leadership world of the nursing manager. The interpretations resulted in a second level of working hypotheses (after those used in the coaching sessions). Thus the systems psychodynamic data were sorted (Terre Blanche et al. 2006) to best describe the constructions presented by the data resources (Haslebo 2000). The aim was to arrive at a systemic general hypothesis that connects the behaviour of the individual participants with the collective (Cilliers \& Smit 2006).

At this point the researchers thoroughly explored the data in terms of saturation in ensuring that they 'have acquired a satisfactory sense of what is going on' (Terre Blanche et al. 2006:422). The data provided a richness that would ensure the clear description of the systems psychodynamic theory. It was therefore not necessary to extend the sample beyond the six participants.

\section{ETHICAL CONSIDERATIONS}

Ethicality (Terre Blanche, Durrheim \& Painter 2006) was ensured by having the leadership coaching programme approved by the hospital authorities. This was followed by authorisation letters to the nursing managers to attend coaching during office hours. During the coaching chemistry meeting, the leadership coaching relationship and logistics were explained to the nursing managers. This was followed up by a jointly signed agreement pertaining to their informed consent, voluntary participation, their withdrawal at any time, a guarantee of their privacy and confidentiality in terms of participation and content of the coaching sessions.

\section{TRUSTWORTHNESS}

The notion of trustworthiness is based on credibility and validity (Denzin 1989; Denzin \& Lincoln 1994). Credibility was assured in terms of the competence of both authors as professionally trained in psychology and psychiatric nursing and as researchers 
who have been trained in this leadership coaching model. The study evidenced strong and believable validity in its in-depth (psychological) description, which revealed the complexities of the variables and their interactions from the systemic and psychodynamic perspectives.

The interpretations were peer reviewed (Breverton \& Milward 2004; Camic et al. 2003). Two independent psychologists, to whom the theoretical model is well known, were asked to investigate the dependability of the findings (which were found to be positive). In the discussion with one psychologist, reflexivity was discussed in terms of the coach being a white male working with a largely white and exclusively female group of participants. Afterwards, she concluded that the findings were free of disturbances in terms of cross-diversity dimensions. Both peer reviewers agreed that the data reached a point of saturation.

\section{FINDINGS AND DISCUSSION}

The findings are presented according to the participants' coaching experiences as they manifested within the six core behavioural constructs, namely anxiety, task, role, authorisation, boundaries and identity.

\section{Anxiety}

Participants described their coaching experience as follows: 'it was initially strange, until you understand what it is about', 'an intense way of learning about yourself', 'something I have never experienced at work', 'thought provoking', 'emotionally challenging and rewarding', 'the greatest learning experience I have ever had', and 'something I would recommend to all nursing staff'. The coach's task and style were described as follows: 'initially weird', 'intensely attentive', 'a very good listener - to the deep stuff', 'making connections that gave me many aha-moments', 'I now understand what coaching is' and 'what it could add to the quality of relationships and leadership in the hospital'. The interpretation was made that participants could significantly move from projecting their anxiety onto the coach and coaching as containing and transitional objects, towards becoming more aware of their own dynamics, owning their learning and integrating the coaching style into their leadership repertoire (Czander 1993).

Participants defended against their experienced anxiety, as described by Bion (1970). Their dependence anxiety manifested in survival and performance anxiety. One participant remarked that 'coaching challenged my comfort zone big time'. This represented a split between what was expected (which participants described as 'that he will tell me how to do my job' and 'I thought it was going to be like a training session') and reality ('I now realise that coaching is about finding out for myself what works for me'). This was accompanied by flight responses such as their occasional avoidance of working on the coaching task. One participant said that 'I soon realised that coaching is about my leadership role and not about gossiping about the other people in my life'. The above behaviour was driven by high levels of frustration and anger which triggered their counter-dependence, directed at the coach as their object of anger as well as of envy. They used projection ('I was so mad at him'), regression ('If he could only tell me what to do') and envious attack ('I was blaming the coach for not doing his

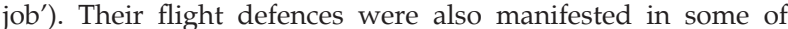
them blaming the coach for his incompetence - 'his inability' to 'control my anxiety'.

This was interpreted as their persecutory transference against the intimacy of the here-and-now coaching relationship (Stapley 2006). Participants reported on their 'profound learning' while working through these experiences. One participant remarked that 'I now realise that without frustration, learning is limited'. Some participants added that the coach exhibited an important leadership dynamic by staying in role and containing the anxiety without judging, memory or desire (Brunner et al. 2006). Another participant added that 'I never thought leaders need to contain behaviour on behalf of others'.

Participants became aware of what their work systems are projecting onto them and how they take the projections in - their valences and projective identifications (Obholzer \& Roberts 1994). Working through their anxiety and confusion led the way towards taking up an independent position in which they started to own their own behaviour and take responsibility for structuring the coaching sessions themselves. One participant said that 'I made an excellent - at least I thought so - hypothesis about how I deny my anger towards that doctor who bullies $\mathrm{me}^{\prime}$. Another added that 'at the start of the third-last session I told the coach what I wanted to explore and I gave my own interpretations of my experiences'. Towards the end of the coaching sessions, two participants moved towards interdependence when they started to report back on 'testing my new behaviour with others' and processing the implications of how others experience them. It was the authors' experience that this movement took longer compared to other reported cases (such as the case concerning Information Technology staff mentioned in Cilliers 2005). This was interpreted as an indication of how the nursing managers were caught up in the hospital system domain (Bain 1998), with its strict rules and strong defences in the relationships between the different authority levels - the nursing staff, administration and doctors.

Participants reported on their learning about how their (mostly unconscious) anxiety acts as a driving force of their own behaviour in their leadership roles. One participant expressed it thus: 'I realise that I defend against anxiety to stay safe and uninvolved when the doctors shunt me around'. They reported on their insight that this dynamic between themselves and the coach (as the authority figure in the session) mirrored (Campbell \& Huffington 2008) their relationships with their direct reports as well as with the hospital administration in terms of the authority dynamics.

Thisled to working hypothesis 1. Participants experienced anxiety which manifested in basic assumption functioning dependency and flight/flight, accompanied by splitting, projection and regression as defences. Coaching allowed them to work through the process of exploring these defences, to develop a curiosity about their own feeling and thinking behaviour and eventually to own that which belongs to them and give up that which does not. They learned that these coaching behavioural processes are mirrored in their role as leaders towards colleagues, and that they need to contain the anxiety of their co-workers and manage the projections in a more conscious manner.

\section{Task}

Participants described their structured, nursing manager primary task with clarity and pride. As evidence, they referred to their many thick and detailed files containing their job content (job descriptions, key performance areas, rules, procedures, structures). The interpretation was made that the linear nature (input, throughout, output) of their structured task acted as a container for their performance anxiety against the complexity of taking up a dynamic leadership role (see Huffington et al. 2004). Their defences were the following: avoidance (which manifested in their preference to speak about how their direct reports did not behave correctly), denial (which was expressed as 'I thought that leadership can be prescribed in a how-to-do-it file'), simplification (manifested in expression such as 'I realise that I keep myself busy with files', 'I am so busy with administration', 'so office bound' that 'I do not get involved in people matters', 'I do not walk the floors / do not connect with my people as a leader') and isolation (one participant said 'I get so tired of the difficulties of dealing with people that I lock myself in the office and just do administration'). Participants realised that their defences led to anti-task behaviour and detachment from their 
primary task (Klein 2005), which is to connect with their direct reports and colleagues.

Consequently, working hypothesis 2 emerged. Participants split their nursing manager task between the mechanics and dynamics of the task. They preferred to attach themselves to the simplicity of the task as contained in their files and detach from the complexity of demanding interpersonal relationships with subordinates and colleagues. Coaching allowed them to shift their competence towards including and balancing both parts.

\section{Role}

Participants were clear on their normative roles (the rational job content), but less so on their experiential and phenomenal roles (Obholzer \& Roberts 1994). In exploring their experiential role (the individual's own perception of her performance), participants initially struggled to talk about themselves. Examples of avoiding defences against being honest and open with the self were, 'I am not used to talk[ing] about my own performance' and 'I am afraid people will think I brag'. They reported how they continuously, subjectively introject the objective (normative) role. The comment, 'I realise how I only do the parts of the role that I like and just ignore the parts I don' $t$ ' serves as an example. They expressed their difficulty in taking up the leadership role: 'maybe leadership is far more demanding than I thought'. In exploring their phenomenal role (the individual's perception of how others see her performance), most participants reported their reluctance to know others' views of them. Their avoidance manifested in comments such as, 'people don't give honest feedback' and 'they only gossip about everyone'. They later realised that their reluctance acted as a defence against (on one level) knowing and being vulnerable and (on a deeper level) taking on and taking in the projections of the other.

The theme concerning the reluctance of becoming aware of others' projections exhibited greater depth. In the exploration of their experiential role, some participants referred to their fear of physical contamination by germs and viruses in the hospital. In the subsequent exploration of their phenomenal role, they gave evidence of being exposed to emotional-toxicogenic practices (Fox \& Spector 2005) and bullying (Babiak \& Hare 2006). Examples mentioned were inconsistency, a lack of respect, anti-social behaviour and the abuse of power (manifesting in manipulation and shouting). According to Porter-O'Grady and Malloch (2007), this toxicity in the culture of health care organisations stimulates unconscious forces of control, conflict, hostility and rigidity - extremely irrational and dysfunctional behaviour, which can eventually destroy the vitality of the organisation. The above behaviour was interpreted as indicative of the participants' fear of psychological and specifically emotional contamination in a hospital system, experienced as emotionally toxic.

The incongruence between the three role parts highlighted above indicated high levels of role anxiety (Newton et al. 2006). Most of the coaching was spent on the deconstruction, alignment and reconstruction of these parts. The participants' learning concerned the complexity of taking up the leadership role and managing the boundaries between the rational and the perceptions of self and other. This was expressed in the comments 'I never realised the importance of how I feel about myself as leader' and 'how others see me, assess what I do and how'. Most participants reported their learning to be related to how they can use themselves as instruments (French \& Vince 1999) and objects (Klein 1988) in connecting more effectively with their direct reports. Participants' commented that 'I now realise how people project their own stuff onto me' and 'their feedback possibly says more about them and their needs, than about me'.
Working hypothesis 3 consequently evolved. Participants initially attached themselves to and found comfort in the rational part of their role and detached from the complex dynamics of working with their introjections and received projections. Coaching allowed them to explore this incongruence and to work towards the integration of the parts of their roles.

\section{Authorisation}

Initially, most participants were unclear about the meaning of authorisation. After an intervention about how she seemed to be de-authorised in the system, one participant said 'but I am not the authority on the subject' - confusing being authorised with being knowledgeable. The concept was also often confused with power and destruction. The concept needed to be explained according to Hirschhorn's (1997) description - namely, the energy relevant to the performance of the task.

All the participants experienced being formally authorised from above (Haslebo 2000) by their leaders, hospital administration and head office in their normative role. They gave evidence of how their competence was respected in terms of their knowledge (through their academic qualifications), skills (extensive inservice training and experience) and positive attitudes (being employed in a competitive hospital and recognised as an expert). They experienced informal authority in being liked and appreciated by most colleagues and direct reports. Thus, they were able to self-authorise (Brunning 2006).

On the other hand, many experiences of being unconsciously de-authorised were explored (Lawrence 1999, 2000). These experiences led to a sense of not being 'good-enough', low selfregard and a feeling of poor performance. The following serve as examples:

- Participants were authorised in staff meetings with authority figures to deliver on specific projects, only to find out later that authority was being taken back. For instance, it happened that resources such as finances, time or assistance were promised but not delivered in practice. When participants investigated the matter, they were told 'it was not budgeted for', 'you have to do it yourself', or 'make another plan'

- Participants explained the difficulties in working in a matrix organisational design and how their managers 'don't know what they want from whom' because 'they are confused about what matrix means'

- Doctors used their status to bully the nursing staff, by threatening to take their expertise elsewhere, which might lead to the discontinuation of that specific type of surgery in the hospital. The interpretation was reached that although the nursing manager feels humiliated, confused and may loathe the doctors' behaviour, she stays obedient to the legitimacy of the authority figure (Burger 2009) as an object of power in the system. The projection of submission by the authority figure onto the participant is so strong that she can only take it in, which became her projective identification (Klein 1988). This explains how the nursing manager is emotionally seduced (Cytrenbaum \& Noumair 2004) into 'playing along with the behaviour and not report[ing] them'. Thus, the power games are sustained while the participant contains the de-authorisation and the 'messiness' on behalf of the whole hospital system (Wells 1980).

Working hypothesis 4 emerged. Participants experienced being consciously authorised from above, the side and below in their normative role in acknowledgment of their competence. On the other hand, they experienced being unconsciously de-authorised by the power of people in management and leadership positions. Coaching allowed them to understand the dynamics underlying these complex systemic behaviours, how they play along with the power games according to their personal and systemic valences (Czander 1993) and how they could move from a position of victim to wisdom. 


\section{Boundaries}

Participants found the boundary concept the most 'valuable' and 'amazing' in the coaching model, especially the realisation that boundary management serves the institution on the conscious and unconscious levels (Lawrence 1999). On the conscious level boundary management contributes towards an effectively managed institution according to practical, management and professional (medical and nursing) requirements. Participants explored and processed their boundary position with the hospital administration (upwards) and their direct reports (downwards). This was expressed in the following comments: 'we need the policies, rules, administrative and medical procedures', 'I realise that everything in my work is about boundaries and how I manage them!', 'the management of my personal boundaries is essential for having effective working relationships' and 'poor boundary management create [sic] ambiguous situations harming both sides of the relationship'.

On the unconscious level their 'profound learning' related to the unconscious meaning, usage and effect of boundaries on the micro, meso and macro systemic levels.

On the micro level, participants learned how their personal boundary is often compromised in the larger hospital system by their being obliged to work long and extended hours, 'be available $24 / 7$ ', 'know everything about everything and everyone'. Participants reported that the challenge of the coaching became one of not dwelling on the rights and wrongs of past practices, but instead to move forward, creating conditions in which personal boundaries are acknowledged and respected. On the meso level, they learned about time boundaries (as in shift work, visiting hours), space (offices, wards, ICU, germ-free zones), task (how to make a bed, give an injection, who may hand out medication, procedures) and relationship boundaries (the structures of how to deal with head office, doctors, specialists, patients, the public). They explored how the hospital as a 'place of distress, illness and death' needs to manage its boundaries tightly as a defence against the anxiety of pain (Menzies 1993). They realised that command and control emotional outbursts (Porter-O'Grady \& Malloch 2007) and attacks by doctors represent poor boundary management: the projections evident in physicians' irrational outbursts are violations of the nursing manager's boundary. They learned that the doctor 'is saying more about himself than about me' and that they need to manage their boundary in such a way as to 'not let him enter my personal space'. On the macro level, participants became aware of their system domain defences (Bain 1998; Kilburg 2006), which refer to health care as practised in a large hospital, its structures, processes and content, as well as its well established, but unconscious, methods of dealing with physical and emotional anxiety. Their learning on all three systemic levels was congruent with Menzies' (1993) research into how socially constructed defence systems operate in hospitals to preserve and contain the high levels of anxiety.

Working hypothesis 5 was now formulated. Participants became aware of how the hospital requires strict boundary management to contain the intensity of the system's survival anxiety, of the importance and nature of the interpersonal boundaries between themselves and their leaders, colleagues and direct reports, and of how they manage their personal boundaries towards becoming more authorised in their role as nursing managers.

\section{Identity}

Convincing evidence was processed to deduce the effectiveness of participants' job performance in terms of outputs and agreement in their performance management discussions with hospital administrators. It was interpreted that all the participants' work identities were (on the conscious level) intact with reference to being professionally well trained, technically competent, organisationally authorised in their role, and personally authorised on the intellectual, emotional and motivational levels.
Despite this evidence, most participants referred to their constant dissatisfaction with their own performance. They compulsively asked questions about what they were doing wrong. Speaking from their experiential roles, they were always pressuring themselves to do more, perform better and to be more attentive to their staff and patients. One participant said that 'something is driving me towards ... I don't know what'. They reported that work had become more important than their personal lives. Three participants reported that they experienced nervousness and guilt when they were not actively involved in something. For them, it is as if 'it is important to be seen to be busy'. Three reported that their hospital work has caused them ill health (constant flu, migraines) and even 'negatively interfered' with and 'messed up' their private lives. They reported using private time to study further and/or read about hospital and nursing issues and added that when they take a vacation, they derive little pleasure from it. Speaking in terms of their phenomenal roles, they reported that they think their co-workers also regard their performance as below average. Some participants reported feeling insecure about their jobs, unappreciated and unrecognised. Some felt left out at times of promotion and generally conveyed a message of performance anxiety to comply with the demands in the system. They were motivated by approval, feared rejection and worried that others might perceive them as inferior. Some participants used their free time for shopping (as a flight and compulsive response) 'but then again, we earn so little that I get frustrated because I cannot buy anything expensive'

The above was interpreted as identity-based conflict (PorterO'Grady \& Malloch 2007 - as opposed to interest-based conflict), which is circumstantial and rooted in the unconscious need for dignity, recognition, safety, control, purpose and efficiency. The containment of caring and nurturing being projected by the system (Klein 1988) onto the role of nursing manager - 'to carry the hospital's emotional stuff' - becomes the impossible task (Campbell \& Gronbaek 2006). 'It is [an] unbearable' and 'overwhelming' task for which no one will ever be good enough (Klein 1988).

In terms of forming attachments (Huffington et al. 2004), most participants shifted from the initial defence against their fear of intimacy (using avoidance and resistance) towards forming more secure and deeper attachment relationships with the coach, themselves and their colleagues. This was evident in how their self-confidence grew, how they became more realistically involved in their work, how their job satisfaction increased and how they started to challenge their own styles - taking up opportunities to explore instead of staying in the hopeless and helpless positions. Most participants reported moving towards balancing their personal and work lives, which indicated using less defensive behaviour and a movement towards more optimal attachment formation (Campbell 2007). The coaching process facilitated participants in facing their implicit identity demands and attempting to discover ways to differentiate between 'what is mine and what is not mine', and therefore to take up their role with more realism.

Working hypothesis 6 consequently evolved. Participants' work identity was clear in terms of their conscious job performance, but burdened by the organisational expectations that they must unconsciously contain systemic anxiety. Because this irrational content does not belong to them, it creates incomprehensible anxiety which the individuals cannot process by themselves. Coaching allowed them to explore, disentangle and differentiate between illusion, fantasy and their reality with the aim of understanding the intricacies of the projections. They were brave enough to give up their ignorance in favour of heightened awareness - they experienced 'a mini-death of a known way of being' (Bain 1998:416). 
Congruent to the aim of the research referring to the learning experiences of participants, the nature and depth of their learning were investigated. With reference to the theories of Argyris (1994) and Taylor (2007), it could be said that this study provided evidence of unlearning, evolution and adaptation. Unlearning was evident in that participants stopped their immediate defensive responses by asking the self 'what is going on here?' Evolution was evident in that participants moved from being unconscious about the impact of their leadership role towards awareness of how their self-authorisation leads to impactful interpersonal relationships. Adaptation was evident in that participants took up their leadership role in a growing awareness of their boundaries and their impact on others in the hospital system.

Next, the criteria for organisational learning according to the systems psychodynamic perspective were investigated (Bain 1998; Campbell \& Huffington 2008:78; French \& Vince 1999:7-19; Meznar \& Nicolini 1995).

\section{Reflection space and containment}

The coaching sessions served as a space for reflection in which participants took up their roles as learners with respect to their psychodynamic primary task as nursing managers. This occurred while the coach was acting as a container of the anxiety and its defences. This process was characterised by eagerness, curiosity and intensity in exploring new possibilities of which they were previously unaware. Participants crossed the boundary out of the project with significantly more 'executive wisdom' (Kilburg 2006; Kilburg \& Diedrich 2007), which is defined as taking up the leadership role with an openness to experience and a creative exploration of own, team and organisational behaviours towards a cognitive understanding, a strong sense of self, and a systemic awareness of process and dynamics.

\section{The evolution of the organisational container and the contained}

On the macro level participants showed insight into the dynamics of the system domain defences in health care; on the meso level they showed insight into the socially constructed defences in their own hospitals; while on the micro level they explored and understood the complexities of their own defensive leadership behaviour - the behaviours that existed below the surface and were as such controlling and determining their and others' behaviour. They developed their containment leadership competence (Bion 1970).

\section{Interdependence}

Participants moved from dependence and non-ownership towards independence and partial ownership in their leadership roles, with some evidence of interdependence (see Stapley 2006). Their experience of their work seemed less fragmented and more inclusive of the system domain's primary task. They became more robust in their support for themselves as well as for their colleagues as they overcame their defensive behaviours.

\section{Exploration of the dynamic primary task}

Participants applied the concepts of primary task, off-task and anti-task behaviour to their coaching learning as well as their leadership roles. They learned to differentiate between what is relevant and appropriately complex (those aspects of the leadership role that are congruent to their primary task), and what is irrelevantly simplistic (those aspects that made them defend against anxiety, for instance by using fight and flight responses). They learned to self-regulate (see Campbell 2007) and to respond to the rational aspects of their primary task with insight and understanding, and in terms of maintaining effective relationships between themselves and the hospital administration, their colleagues, their direct reports and other professionals (such as the doctors).

\section{Boundary management}

Awareness of the dynamic meaning of personal, interpersonal and organisational boundaries facilitated participants' effective management of the boundaries of their leadership role in the here-and-now (see Lawrence 1999).

\section{Taking up the leadership role with authority}

Participants learned the cognitive meaning of leadership and its appropriate levels of authorisation (see Kets de Vries 2007). They took up their leadership role experientially, which enlarged their leadership spectrum and behavioural repertoire. They could differentiate between rational and irrational leadership behaviour as well as the accompanying defensive behaviours such as denial, introjections, projections and projective identifications. This enhanced their competence in self-authorisation and capacity for making decisions and taking action.

\section{CONCLUSION AND RECOMMENDATION}

The reported leadership coaching experiences of the nursing manager indicated individual (micro level), team (meso level) and organisational (macro level) learning. The generated working hypotheses were integrated into the following general systems psychodynamic hypothesis: coaching created a reflective space for the development of leadership awareness. Participants moved from being mostly ignorant and unconscious containers of system domain, socially constructed and personal defences, to containers of personal and leadership awareness. They took up their leadership roles with significantly more self-authorisation. While being aware of and managing their personal and organisational boundaries, they started to integrate their normative, experiential and phenomenal roles. These were manifested in their capacity for creating new thoughts, processed feelings and responsible actions. Their depth and the nature of the learning and behavioural change could be seen as the first steps towards building an authentizotic organisation.

Thus, through leadership coaching, the nursing manager developed a dynamic awareness of her individual identity, how she relates to others and what she represents in the hospital system as well as the competence to ask questions about her dynamic experiences. She took up her leadership role according to the definition of managing the boundaries between what is inside and what is outside.

Although the researchers tried to minimise subjectivity in the study, it played a role in conducting the coaching sessions as well as in the data analysis and interpretation of the data. This happened on occasion when the coach strongly identified with the hospital environment, unconsciously wanting to defend nursing staff (having close family members trained in the nursing sciences) and the doctors (having had a doctor as a father). These transference dynamics were discussed and contained by the authors.

It is recommended that these participants' learning be followed up regularly, to ensure that the effect of the learning and skills is not diluted by system domain defences. This leadership coaching model should be further researched and refined amongst all nursing and administrative staff and on different levels in hospitals and health care. It is also recommended that emotional toxicity in hospitals is investigated further.

\section{REFERENCES}

Argyris, C., 1994, On organisational learning, Blackwell, Oxford. Armstrong, D., 2005, Organisation in the mind. Psychoanalysis, group relations and organisational consultancy, Karnac, London.

Babiak, P. \& Hare, R., 2006, Snakes in suits. When psychopaths go to work, Harper Collins, New York. 
Bain, A., 1998, 'Social defences against organisational learning', Human Relations 51(3), 413-429.

Bion, W.R., 1961, Experiences in groups, Tavistock, London.

Bion, W.R., 1970, Attention and interpretation, Tavistock, London.

Bion, W.R., 2003, Learning from experience, Karnac, London.

Blackman, J.S., 2004, 101 Defences. How the mind shields itself, Brunner-Routledge, New York.

Breverton, P. \& Millward, L., 2004, Organisational research methods. A guide for students and researchers, Sage, London.

Brunner, L.D., Nutkevitch, A. \& Sher, M., 2006, Group relations conferences. Reviewing and exploring theory, design, role-taking and application, Karnac, London.

Brunning, H., 2006, Executive coaching. Systems-psychodynamic perspective, Karnac, London.

Burger, J.M., 2009, 'Replicating Milgram. Would people still obey today?', American Psychologist 64(1), 1-11.

Camic, P.M, Rhodes, J.E. \& Yardley, L., 2003, Qualitative research in psychology, American Psychological Association, Washington.

Campbell, D., 2007, The socially constructed organisation, Karnac, London.

Campbell, D. \& Gronbaek, M., 2006, Taking positions in the organisation, Karnac, London.

Campbell, D. \& Huffington, C., 2008, Organisations connected. A handbook of systemic consultation, Karnac, London.

Chapman, L. \& Cilliers, F., 2008, 'The integrated experiential executive coaching model: A qualitative exploration', South African Journal of Labour Relations 32(1), 63-80.

Cilliers, F., 2005, 'Executive coaching experiences. A systems psychodynamic perspective', South African Journal of Industrial Psychology 31(3), 23-30.

Cilliers, F. \& Koortzen, P., 2005, 'Conflict in groups. The CIBART model', HR Future October, 52-53.

Cilliers, F. \& Smit, B., 2006, 'A systems psychodynamic interpretation of South African diversity dynamics: a comparative study', South African Journal of Labour Relations 30(2), 5-18.

Clutterbuck, D., 2003, 'Coaching and mentoring at the top', Management Today 19(5), 38-40.

Colman, A.D. \& Bexton, W.H., 1975, Group relations reader 1, A.K. Rice Institute, Jupiter.

Colman, A.D. \& Geller, M.H., 1985, Group relations reader 2, A.K Rice Institute, Jupiter.

Coutu, D. \& Kaufman, C., 2009, 'What can coaches do for you?', Harvard Business Review January, 91-97.

Cytrynbaum, S. \& Noumair, A., 2004, Group relations reader 3, A.K. Rice Institute, Jupiter.

Czander, W.M., 1993, The psychodynamics of work and organizations, Guilford, New York.

Denzin, N.K., 1989, The research act, Prentice Hall, Englewood Cliffs.

Denzin, N.K. \& Lincoln, Y.S., 1994, Handbook of qualitative research, Sage, Thousand Oaks.

Fox, S. \& Spector, P.E., 2005, Counterproductive work behaviour. Investigations of actors and targets, American Psychological Association, Washington.

Fraher, A., 2004, A history of group study and psychodynamic organisations, Free Association, London.

French, R. \& Vince, R., 1999, Group relations, management, and organization, Oxford University Press, New York.

Goldsmith, M., Lyons, L. \& Freas, A., 2000, Coaching for leadership: How the world's greatest coaches help leaders learn, Jossey-Bass, San Francisco.

Gould, L.J., Stapley, L.F. \& Stein, M., 2001, The systems psychodynamics of organisations, Karnac, London.

Grossman, S.C. \& Valiga, T.M., 2009, The new leadership challenge. Creating the future of nursing, Davis, Philadelphia.

Harvard Business Essentials, 2004, Coaching and mentoring. How to develop top talent and achieve stronger performance, Harvard Business School, Boston.

Haslebo, G., 2000, Systems and meaning. Consulting in organisations, Karnac, London.

Henning, E., Van Rensburg, W. \& Smit, B., 2004, Finding your way in qualitative research, Van Schaik, Pretoria.

Higgs, P. \& Smith, J., 2003, Rethinking truth, Juta, Lansdowne.
Hirschhorn, L., 1993, The workplace within: Psychodynamics of organizational life, MIT, Cambridge.

Hirschhorn, L., 1997, Reworking authority. Leading and following in the post-modern organisation, MIT, London.

Huffington, C., Armstrong, A., Halton, W., Hoyle, L. \& Pooley, J., 2004, Working below the surface. The emotional life of contemporary organisations, Karnac, London.

Jaques, E., 1990, Creativity and work, International Universities, Madison.

Kegan, R., 1994, In over our heads. The mental demands of modern life, Harvard University, Cambridge.

Kets de Vries, M.F.R., 1991, Organisations on the coach. Clinical perspectives on organisational behaviour and change, JosseyBass, San Francisco.

Kets de Vries, M.F.R., 2001, The leadership mystique, Prentice Hall, London.

Kets de Vries, M.F.R., 2007, Coach and couch, Palgrave, London.

Kets de Vries, M.F.R. \& Engellau, E., 2007, ‘Organisational dynamics in action', in R.R. Kilburg (ed.), Executive wisdom. Coaching and the emergence of virtuous leaders, pp. 25-34, American Psychological Association, Washington.

Kilburg, R., 2006, Executive wisdom, American Psychological Association, Washington.

Kilburg, R. \& Diedrich, R., 2007, The wisdom of coaching: Essential papers in consulting psychology for a world of change, American Psychological Association, Washington.

Klein, L., 2005, Working across the gap. The practice of social science in organisations, Karnac, London.

Klein, M., 1988, Envy and gratitude and other works 1946-1963, Hogarth, London.

Lawrence, W.G., 1999, Exploring individual and organisational boundaries. A Tavistock open systems approach, Karnac, London.

Lawrence, W.G., 2000, Tongued with fire. Group in experience, Karnac, London.

Lawrence, W.G., Bain, A. \& Gould, L., 1996, The fifth basic assumption, Tavistock, London.

Levinson, H., 2006, The psychology of leadership, Harvard Business School, Boston.

Lowman, R.L., 2002, The handbook of organizational consulting psychology, Jossey-Bass, San Francisco.

McGovern, J., Lindemann, M., Vergara, M., Murphy, S., Barker, L., Warrenfeltz, R., 2001, 'Maximizing the impact of executive coaching. Behavioural change, organisational outcomes and return on investment', The Manchester Review 6(1), 1-10.

McKenna, D.D. \& Davis, S.L., 2009, 'Hidden in plain sight: The active ingredient of executive coaching', Industrial and Organisational Psychology 2(3), 244-260.

Menzies, I.E.P., 1993, The functioning of social systems as a defence against anxiety, Tavistock, London.

Meyer, T.N.A. \& Boninelli, I., 2007, Conversations in leadership. South African perspectives, Knowres, Randburg.

Meznar, M.B., \& Nicolini, D., 1995, 'The social construction of organisational learning', Human Relations 48(7), 24-36.

Miller, E.J., 1993, From dependency to autonomy: Studies in organization and change, Free Association, London.

Neumann, J.E., Keller, K. \& Dawson-Shepherd, A., 1997 Developing organisational consultancy, Routledge, London.

Newton, J., Long, S. \& Sievers, B., 2006, Coaching in depth. The oroanisational role analysis approach, Karnac, London.

Obholzer, A. \& Roberts, V.Z., 1994, The unconscious at work, Routledge, London.

Orenstein, R.L., 2007, Multidimensional executive coaching, Wiley, New York

Peltier, B., 2001, The psychology of executive coaching. Theory and application, Brunner-Routledge, New York.

Peterson, D.B., 1996, 'Executive coaching at work. The art of one-on-one change', Consulting Psychology Journal: Practice and Research 48(2), 78-86

Porter-O'Grady, T., \& Malloch, K., 2007, Quantum leadership. A resource for health care innovation, Jones \& Bartlett, Boston.

Savage, C.M., 2001, 'Executive coaching: Professional self-care for nursing leaders', Nursing Economics July, 25-31. 
Schafer, R., 2003, Insight and interpretation. The essential tools of psychoanalysis, Karnac, London.

Shapiro, E.R. \& Carr, A.W., 1991, Lost in familiar places: Creating new connections between the individual and society, Yale University, London.

Smit, B. \& Cilliers, F., 2006, 'Understanding implicit texts in focus groups from a systems psychodynamic perspective', The Qualitative Report 11(2), 302-316, viewed 27 March 2010 from http://www.nova.edu/ssss/QR/QR11-2/smit.pdf.

Sperry, L., 2004, Executive coaching. The essential guide for mental health professionals, Brunner-Routledge, New York.

Stapley, L.F., 1996, The personality of the organisation. A psychodynamic explanation of culture and change, Free Association, London.

Stapley, L.F., 2006, Individuals, groups and organisations beneath the surface, Karnac, London.

Stern, L., 2001, Executive coaching handbook: Principles and guidelines for a successful coaching partnership, Executive Coaching Forum, Boston.

Stout Rostron, S., 2009, Business coaching. Wisdom and practice. Unlocking the secrets of business coaching, Knowledge Resources, Randburg.

Sullivan, E.J. \& Decker, P.J., 2009, Effective leadership and management in nursing, Pearson Prentice Hall, Upper Saddle River.
Taylor, R.G., 2007, 'Learning in uncertain times', in T.N.A. Meyer \& I. Boninelli (eds.), Conversations in leadership. South African perspectives, pp. 162-179, Knowledge resources, Randburg.

Terre Blanche, M., Durrheim, K. \& Painter, D., 2006, Research in practice. Applied methods for the social sciences, UCT Press, Cape Town.

Turquet, P.M., 1974, 'Leadership - the individual in the group', in G.S. Gibbard, J.J. Hartman \& R.D. Mann (eds.), Analysis of groups, pp. 15-26, Jossey-Bass, San Francisco.

Van der Colff, J.J. \& Rothmann, S., 2009, 'Occupational stress, sense of coherence, coping, burnout and work engagement of registered nurses in South Africa', South African Journal for Industrial Psychology 35(1), Art. \#423, 10 pages.

Van Manen, M., 1990, Researching lived experience, State University of New York, Toronto.

Wells, L., 1980, 'The group-as-a-whole: A systemic socioanalytical perspective on interpersonal and group relations', in C.P. Alderfer \& C.L. Cooper (eds.), Advances in experiential social processes, vol. 2, pp. 165-198, Karnac, London.

Will, B. \& Codrington, G., 2004, 'Coaching: Perspectives on leadership', Management Today 20(7), 51-53.

Willem, A., 2003, 'Coaching: Obtaining wisdom from the relationship', Management Today 18(10), 50-51. 